\title{
A CONGENITAL MYOPATHY OF UNKNOWN ORIGIN
}

\author{
J. A. LEVY * \\ N. MACHA * \\ A. M. 8. TOLEDO *** \\ F. C. REINACH *** \\ L. L. GEORGE****
}

A review of the literature on myopathies did not disclose sufficient data to characterize the case here presented among the classically described myopathies. Thus, the authors carried out a clinical, an histochemical and ultrastructural analisys in order to contribute to the characterization of this peculiar muscle pathology.

\section{CASE REPORT}

The patient, a three-year-old boy, was brought to our Muscle Disease Clinic in 1975, with a clinical history of difficulty for climbing stairs ever since he had learned to walk. He was said to have been in good health before this, even though he was only able to sit up without some kind of support at the age of 10 months and only started to walk at the age of 20 months. The clinical examination was normal, except for the presence of dome-shaped elevated palate; the neurological examination was normal, except for the presence of a slightly myopathic gait and the impossibility of climbing stairs without the help of his hands: myopathic rise; hypotony of lower limbs and a slight muscle hypotrophy of limb girdle and the femoral quadriceps muscles. EMG recording of femoral quadriceps, done bilaterally, revealed potentials of decreased amplitude and duration, as well as a decrease in the interference potencials. The laboratory investigation showed a normal CPK and the urine test was normal as far as innate metabolic errors are concerned.

A muscle biopsy from the quadriceps was performed. Part of this material was fixed in $10 \%$ neutral formalin and embedded in parafin. For light microscope observations, 7 um sections were stained with Hematoxilin and Eosin ( $H$ and $E)$. For histochemistry, the following histochemical methods were used: periodic-acid-schiff (PAS); PAS after alpha-amylase digestion for 30 minutes at $37 \circ \mathrm{C}$; colloidal iron (Hale's method modified by Muller) and Alcian Blue (AB) at pH 2.5 (Pearse, 1968).

For electron microscopy, fragments from the biopsy material were fixed in 2\% glutaraldehyde in phosphate buffer, pH 7.2, and post-fixed in $1 \%$ osmium tetroxide and $0.5 \%$ uranyl acetate, both solutions at $380 \mathrm{mOsm}$ (De Harven, 1967). Embedding was carried out in araldite resin (Luft, 1971). For light microscope observations. thick sections of $500 \mathrm{~nm}$ width, stained with toluidine blue were used. For electron

From the Center of Neurological Investigation of the Medical School of the Universidade de Săo Paulo: *Associated Professor. From the Instituto de Ciências Blomédicas of the Universidade de São Paulo, Histochemical Laboratories: "Assistent Professor. From the Electron Microscope Laboratories: "*Assistent Professor; \#***Bolsista da FAPESP; *****Assistent Professor. 
microscopy, thin sections of $100 \mathrm{~nm}$ width, obtained with a Porter-Blum MT1 microtome were stained with uranil acetate and lead citrate (Reynolds, 1967) and examined through a Zeiss EM 9S-2 electron microscope.

The paraffin-embedded material stained with $\mathrm{H}$ and $\mathrm{E}$ together with the aralditeembedded thick sections stained with toluidin blue and examined under light microscope, revealed the same general features. Thus, light microscopy disclosed the presence of scarce muscle fibers surrounded by abundant adipose tissue, which seems to be a substitute for the loose connective tissue of endo and perymisium (Fig. 1). Crosssections showed fibers of different diameters whereas, in longitudinal sections, no remarkable alterations could be detected. All nuclei appeared peripherally distributed.

The presence of a PAS positive material into the cytoplasm of muscle fibers was detected. This material appeared as compact masses of irregular size and distribution (Fig. 2).

After alpha-amylase treatment, the PAS positive material showed partial digestion. The colloidal iron reaction revealed the same pattern of PAS positivity, while the $A B$ reaction was negative.

Electron microscope observations disclosed the existence of irregularly distributed lesions in the interior of muscle fibers. Three main aspects may be considered here: myofibrilar, sarcoplasmic, and mitochondrial alterations.

Myofibrilis showed damages, but the degree of these lesions varied from one region to another. Aspects observed in these impaired regions were the following: a) disruption of the typical myofibrilar parallelism (Fig. 3). and b) disruption of myofibrils at the $I$ band and $\mathbf{Z}$ line levels (Figs. 3 and 4). Closer observations suggest that disruption begins at I band level, since thick filaments can be seen lying loose in the center of damaged sarcomeres.

Sarcoplasmic alterations can be related to the presence of a very low electrodense material disposed in clusters, and which deforms and dislodges myofibrils (Figs. 3 and 4). These abnormal storage-like areas are not membrane-bounded; also, no organelles, vesicles or any other material was found in their interior. Glicogen granules could be identified in the periphery of these areas (Figs. 5 and 6).

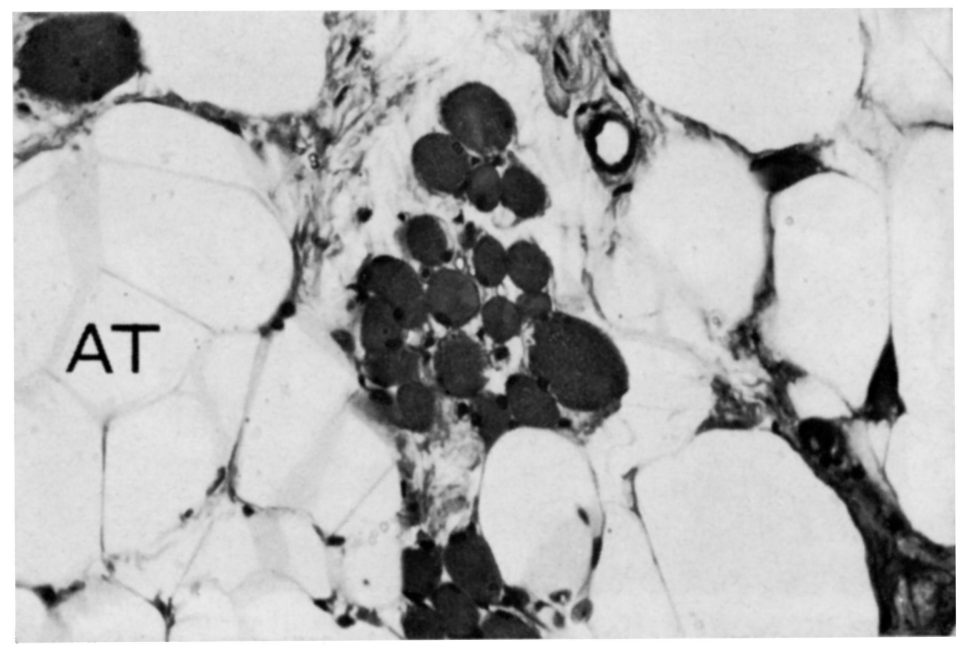

Fig. 1 - Photomicrograph of a paraffin-embedded cross-section showing muscle fibers with different diameters surrounded by abundant adipose tissue $(A T)$. $H$ and E. $\boldsymbol{X} 200$. 


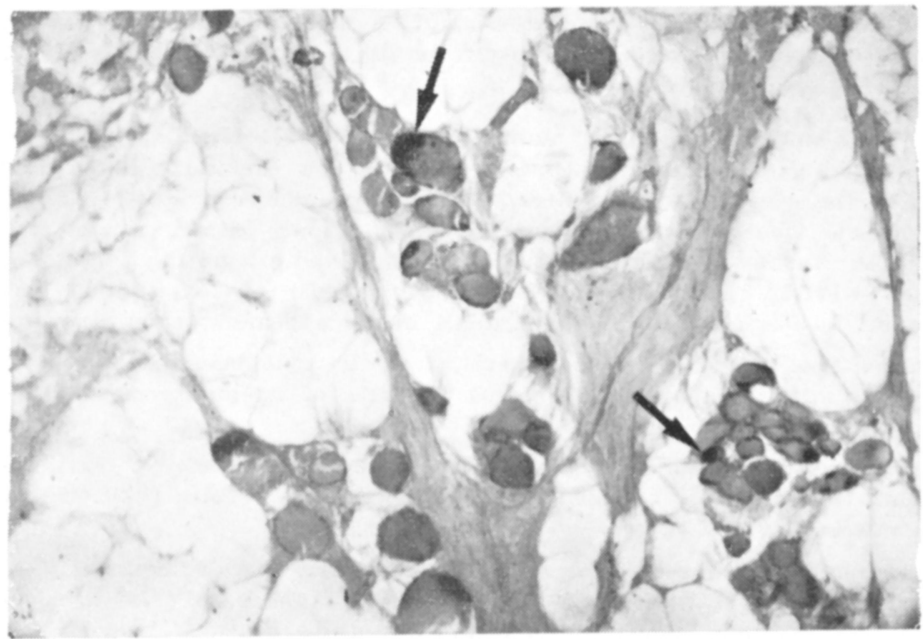

F'ig. 2- Photomicrograph of PAS positive pathological material (arrows) inside muscle fibers. $X 110$.

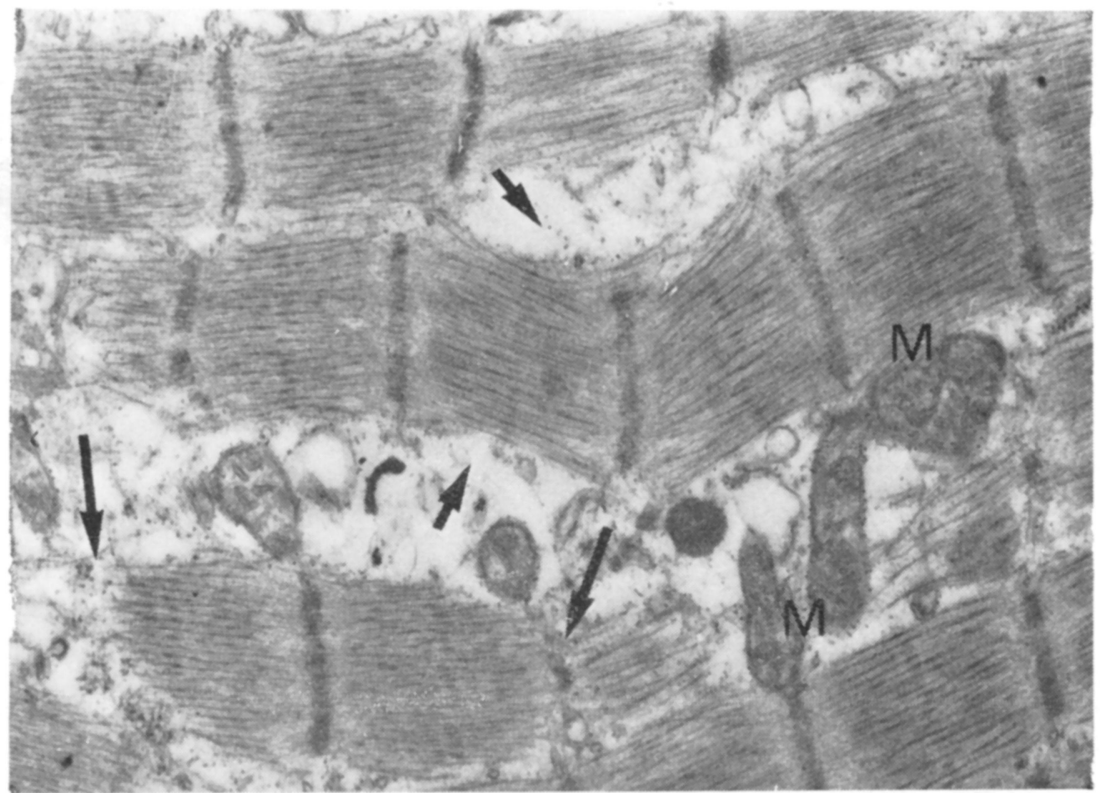

Fig. 3-Electronmicrograph showing intracellular lesions: short arrows indicate sites of accumulation of a low electron dense material dislodging myofibrils. Long arrows indicate disruptions at $I$ band and $\mathrm{Z}$ line levels. In $M$, mitochondriae. X 28,000. 


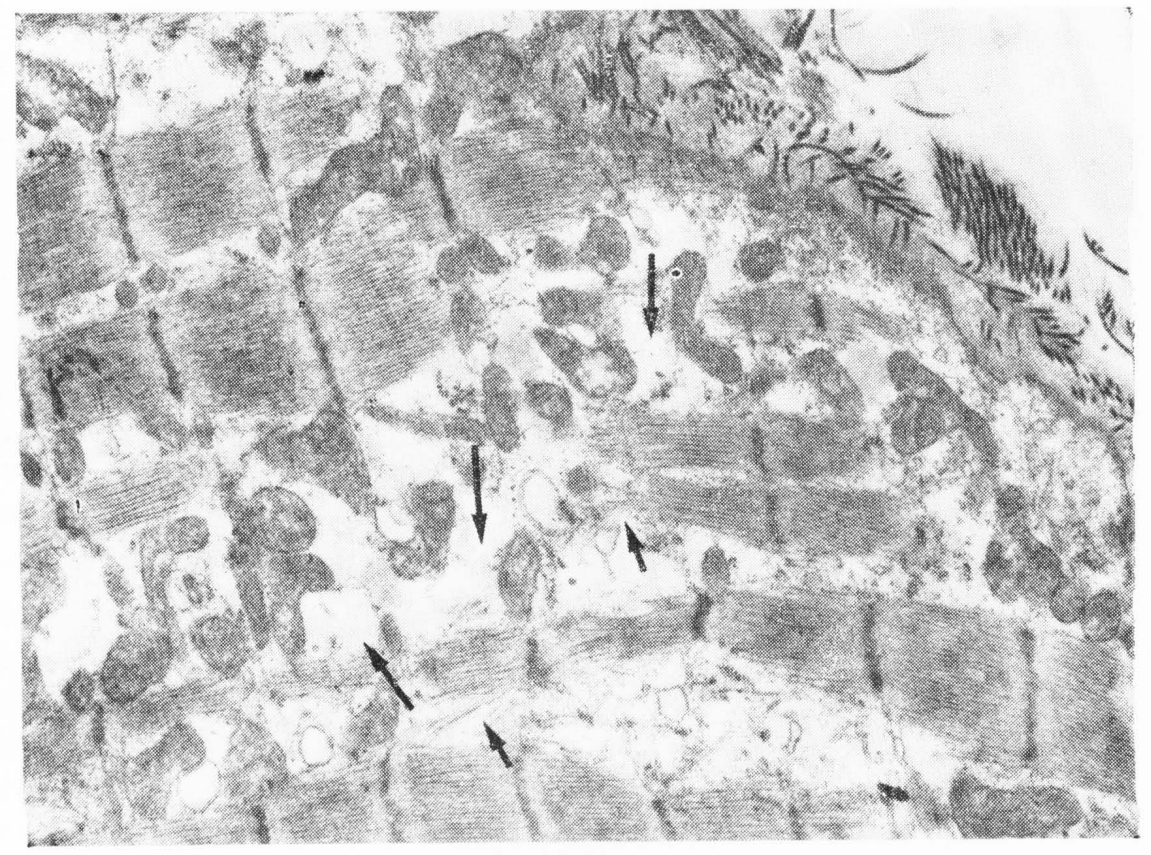

Fig. 4 - Electronmicrograph of a focal lesion near the endomysium showing several dismupted myofibrils (short arrows) and storage of a low electron dense material (long arrows). An abundance of mitochondriae with different sizes and shapes can also be seen. X 15,000.

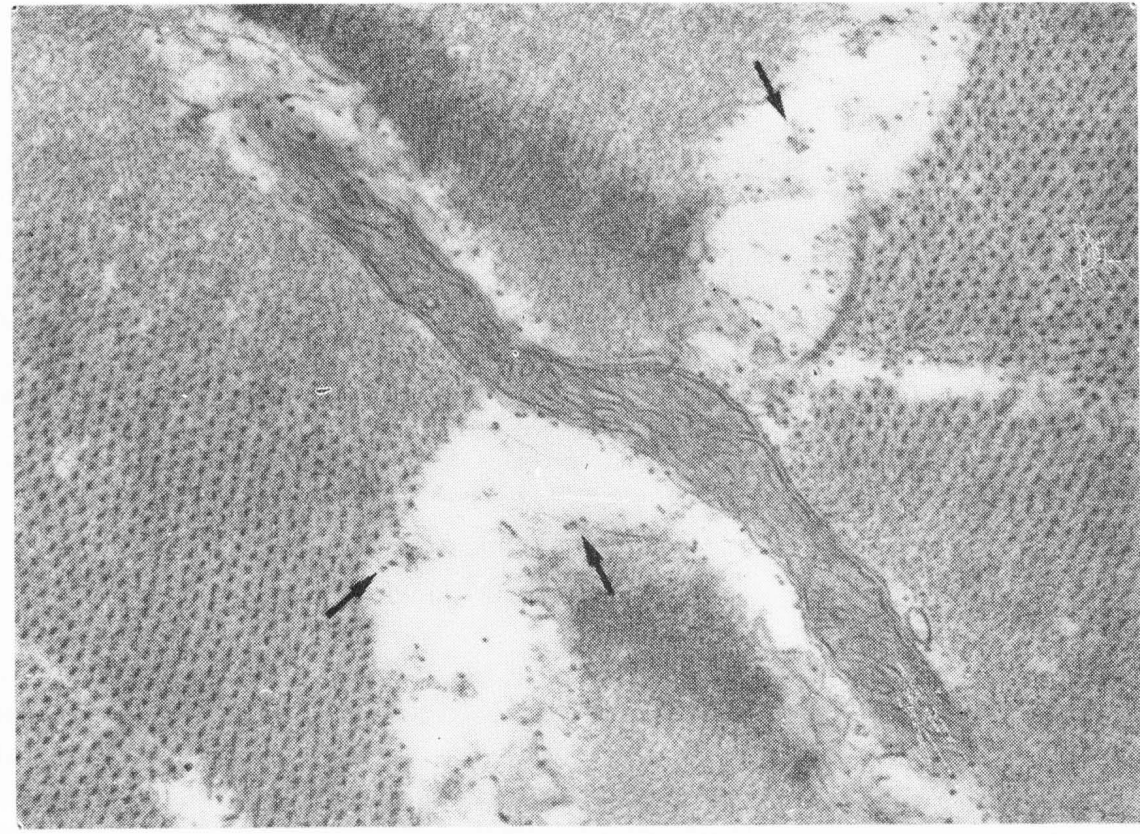

Fig. 5 - Electronmicrograph of the cross-section of a muscle fiber, showing the absence of a membrane at the periphery of a storage-like area. Arrows indicate glycogen granules. X 60,000. 


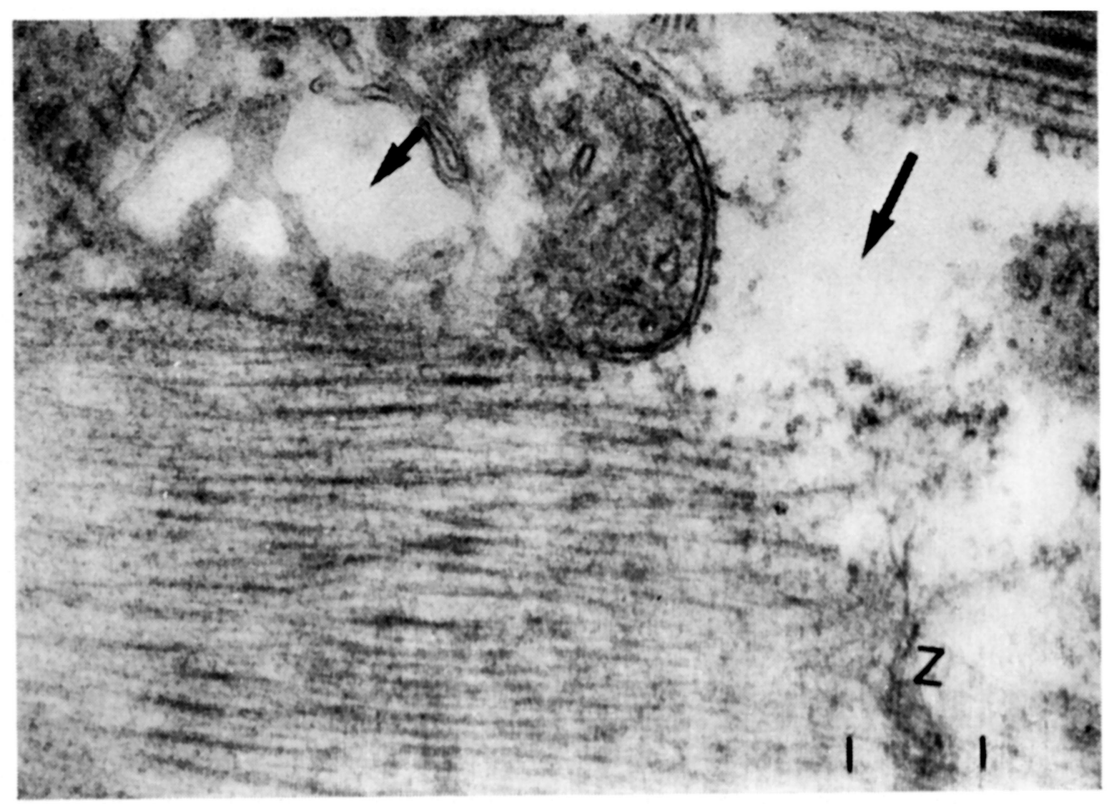

Fig. 6-Electronmicrograph showing a sarcoplasmatic storagelike area not membranebounded (long arrow) and a mitochondria with a similar storage area inside its matrix (short arrow). Under the organelle, a disrupted sarcomere II and $\mathrm{Z}$ ) can be scen. $X 70,000$.

As to mitochondria, several aspects of this organelle can be described. In the regions where there was severe myofibrilar damage, mitochondria of different shapes and sizes - irregularly disseminated - could be found (Figs. 3 and 4). Surrounding these regions mitochondria could be seen, with the appearance of small spherical particles; in some parts they were not present. A few instances of mitochondria, showing a low electron dense material at their matrix (Fig. 6), suggestive of a storage-like area - similar to the one above described in the sarcoplasm - could be detected.

All these alterations were restricted to some regions of the muscle fibers, so that the lesions had a focal character with a gra iual transition to normal tissue. No nuclear or sarcolemal alterations were detected. Absence of typical triads and lack of lipid inclusions could be counted, as still one other intracytoplasmatic alteration.

\section{DISCUSSION}

Glycogen-storage diseases of muscle are the sole inherited muscular diseases in which biochemical abnormalities are known to occur, even though in none of them it is possible to theoretically relate the symptons of the disease to the enzymatic defects (Rowland et al, 1971). One other storage disease of muscle is the one related to lipids (Bradley et al, 1969). Holmes et al (1960) described a myopathy of onset in adult life, with features suggesting a glycogen-storage disease, and in which the material was considered to be a neutral mucopoly- 
saccharid. Karpati et al (1969) described a peculiar polysaccharide accumulation in muscle fibers in a case of cardioskeletal myopathy.

Our histochemical findings suggest the presence of an intracytoplasmatic storage-like material of a polysaccharid nature, probably a neutral polysaccharide, since the $A B$ reaction was negative. The positivity of the colloidal iron reaction as indicated by Pearse was good for the enhancement of the intracytroplasmatic patological areas, in our material; in normal muscle fibers this reaction is positive only for the endomysium. Thus the presence of an abnormal material of polysaccharid nature inside muscle fibers seems to be histochemically determined.

The ultrastructural aspect of the storage-like material found in the muscle biopsy made is quite different from that of glycogen and the regularity of the images obtained suggest it is not an artifact: Analysis of the work of Karpati et al (1969), who report an accumulation of a polysaccharide in muscle (other than glycogen) coupled with our own histochemical findings, indicate that we are probably dealing with a case of a similar myopathy. It should be stressed, however, that Karpati et al (1969) found two different types of storage areas: one unsequestered and one sequestered, that is, not membrane-bounded and membrane-bounded, respectively, and the unsequestered area showed two distinct components. Only one type of unsequestred storage area with a homogeneous material was found in the case herein reported.

Our ultrastructural findings also auggest that myofibrilar disruption could be due to the effect of pressure exerted by the accumulation of this low electron dense material, inside the muscle fibers.

\section{SUMMARY}

Parallel with the clinical and histochemical investigations, an ultrastructural examination of a muscle biopsy specimen was made, in order to detect any slight cellular alterations which cannot possibly be discovered through any other methods, and to identify a muscle disease of unknown origin.

\section{RESUMO}

\section{Miopatia congênita de origem desconhecida}

E relatado um caso de miopatia no qual o quadro clínico difere dos comumente observados nas miopatias descritas na literatura. Paralelamente aos exames clínicos, foram feitas análises histoquímicas e ultra-estruturais de uma biópsia de quadríceps, a fim de detectar alterações celulares que não poderiam ser evidenciadas mediante outros métodos de estudo. Os resultados, juntamente com os dados obtidos nos exames clínicos, são discutidos e analisados, numa tentativa de identificar uma miopatia de origem desconhecida. 


\section{REFERENCES}

1. BRADLEY, W. G.; HUDGSON, P.; GARDNER-MEDWIN, D. \& WALTON, J. N. - A new myopathy associated with abnormal lipid metabolism in skeletal muscle. Lancet I: 495, 1969.

2. DE HARVEN, E. - Methods in electron microscope cytology. In Methods in cancer research. Academic Press, New York, 1967, vol. 1, pag. 3.

3. HOLMES, J. M.; HOUGHTON, C. R. \& WOOLF, A. L. - A myopathy presenting in adult life with features suggestive of glycogen storage disease. J. Neurol. Neurosurg. Psychiat. 23:302, 1960.

4. KARPATI, G.; CARPENTER, S.; WOLFE, L. S. \& SHERWIN, A. - A peculiar polysaccharide accumulation in muscle in a case of cardiosqueletal myopathy. Neurology (Minneapolis) 19:553, 1969.

5. LUFT, J. H. - Improvements in epoxy embedding methods. J. biophis. biochem. cytol.. $9: 409$, 1961.

6. PEARSE, A. G. E. - Histochemistry: Theoretical and Applied. J. A. Churchill Ltd., London, 1968, vol. 1, pags. 307 and 672 .

7. REYNOLDS, E. S. - The use of lead citrate at high pH as an electron opaque stain in electron microscope. J. Cell Biol. 17:208, 1963.

8. ROWLAND, L. P.; DE MAURO, S. \& BANK, W. J. - Glycogen storage diseases of muscle. Problems in biochemical genetics in birth defects. Original Articles Series vol. II no 2, 1971.

Clínica Neurologica - Fraculdade de Medicina da Universidade de São Paulo Caixa Postai 3461 - 01000 São Paulo, SP - Brasil. 